be studied before a definite estimate of risk can be made. At present we consider using verapamil as a supplement to propranolol in patients who are either unresponsive to or cannot tolerate long-acting nitrates. We take great care when adding verapamil to a beta-blocker, and either give a single trial dose of $120 \mathrm{mg}$ on an outpatient basis in the coronary care unit or build up the dose gradually from $40-80$ to $120 \mathrm{mg}$ three times daily.

We thank Dr Moshe Weinstein for encouraging this study and Esther Bassan for the statistical analyses.

\section{References}

${ }^{1}$ Melville KI, Shister HE, Huq S. Iproveratril: experimental data on coronary dilatation and antiarrhythmic action. Can Med Assoc $\mathcal{F} 1964$; 90:761-70.

2 Nayler WG, McInnes I, Swann JB, et al. Some effects of iproveratril (Isoptin) on the cardiovascular system. F Pharmacol Exp Ther 1968; $161: 247-61$

${ }^{3}$ Ferlinz J, Easthope JL, Aronow WS. Effects of verapamil on myocardial performance in coronary disease. Circulation 1979;59:313-9.

4 Neumann M, Luisada AA. Double blind evaluation of orally administered iproveratril in patients with angina pectoris. Am F Med Sci 1966;251 552-6.

5 Sandler G, Clayton GA, Thornicroft SG. Clinical evaluation of verapamil in angina pectoris. $\mathrm{Br}$ Med $\mathcal{7} 1968$;ii :224-7.

${ }^{6}$ Livesley B, Catley PF, Campbell RC, Oram S. Double-blind evaluation of verapamil, propranolol, and isosorbide dinitrate against a placebo in the treatment of angina pectoris. Br Med F 1973;i :375-8.

7 Balasubramanian V, Khanna PK, Narayanan GR, Hoon RS. Verapamil in ischaemic heart disease-quantitative assessment by serial multi-stage treadmill exercise. Postgrad Med f 1976;52:143-7.

${ }^{8}$ Bala Subramanian V, Lahiri A, Paramasivan R, Raferty EB. Verapamil in chronic stable angina. Lancet $1980 ; \mathrm{i}: 841-4$.

${ }^{9}$ Singh BN, Roche AWG. Effects of intravenous verapamil on hemodynamics in patients with heart disease. Am Heart $\mathcal{f} 1977$;94:593-9.
10 Smith HJ, Goldstein RA, Griffith JM, Kent KM, Epstein SE. Regional contractility. Selective depression of ischemic myocardium by verapamil. Circulation 1976;54:629-35.

${ }^{11}$ Roy PR, Spurrell RAJ, Sowton E. The effect of verapamil on the conduction system in man. Postgrad Med $\mathcal{F}$ 1974;50:270-5.

12 Benaim ME. Asystole after verapamil. Br Med f 1972 ;ii:169.

13 Boothby CB, Garrard CS, Pickering D. Verapamil in cardiac arrhythmias. Br Med F 1972;ii:349.

14 Krikler DM, Spurrell RAJ. Verapamil in the treatment of paroxysmal supraventricular tachycardia. Postgrad Med f 1974;50:447-53.

15 Opie LH. Drugs and the heart. III. Calcium antagonists. Lancet 1980;i: 806-10.

${ }^{16}$ Russek HI. Propranolol and isosorbide dinitrate synergism in angina pectoris. Am $\mathcal{F}$ Cardiol $1968 ; 21: 44-54$.

17 Redwood DR, Rosing DR, Goldstein RE, Beiser GD, Epstein SE. Importance of the design of an exercise protocol in the evaluation of patients with angina pectoris. Circulation $1971 ; 43: 618-28$.

18 Opie LH. Drugs and the heart. I. Beta-blocking agents. Lancet 1980;i: 693-8.

19 Jackson G, Atkinson L, Oram S. Reassessment of failed beta-blocker treatment in angina pectoris by peak exercise heart rate measurements. Br Med f 1975; ;iii:616-8.

${ }^{20}$ Schomerus M, Spiegelhalder B, Stieren B, Eichelbaum M. Physiological disposition of verapamil in man. Cardiovasc Res 1976;10:605-12.

21 Woodcock BG, Hopf $R$, Kaltenbach $M$. Verapamil and norverapamil in plasma concentrations during long term therapy in patients with hypertrophic obstructive cardiomyopathy. F Cardiovasc Pharmacol $1980 ; 2: 17-23$

${ }^{22}$ Leon MB, Rosing DR, Bonow R, Lipson LC, Epstein SE. Clinical efficacy of verapamil alone and combined with propranolol in treating patients with chronic stable angina pectoris. Am 7 Cardiol 1981;48:131-9.

${ }^{23}$ Ferlinz J, Turbow ME. Antianginal and myocardial metabolic properties of verapamil in coronary artery disease. Am $\mathcal{F}$ Cardiol 1980;46:1019-26.

${ }^{24}$ Chew CYC, Brown G, Wong M, Shah P, Singh BN, Bolson EL, Dodge HT. The effects of verapamil on coronary hemodynamics and vasomobility in patients with coronary artery disease. Am $\mathcal{F}$ Cardiol 1980; 45:389. (Abstract.)

${ }^{25}$ Nayler WG, Krikler D. Verapamil and the myocardium. Postgrad Med $\mathcal{F}$ $1974 ; 50: 441-6$

(Accepted 24 December 1981)

\title{
Atopy predisposing to acute bronchiolitis during an epidemic of respiratory syncytial virus
}

\author{
I LAING，F RIEDEL，P L YAP， H SIMPSON
}

\begin{abstract}
Thirty-one infants admitted to hospital with acute bronchiolitis during an epidemic of respiratory syncytial virus were compared with a control group of 32 infants to establish whether the two groups differed in atopic background. Past history of respiratory illness, eczema, and present reactions to skin testing differed significantly between the two groups. Thus, infants with acute bronchiolitis had a significantly higher atopic predisposition than the controls.
\end{abstract}

\section{Introduction}

Respiratory syncytial virus is the commonest organism isolated from infants during epidemics of acute bronchiolitis. During such an epidemic, however, only a few infants develop the clinical features of acute bronchiolitis. The possibility that respiratory syncytial virus selects out of a given population "only those infants genetically predisposed to wheeze on the basis of an atopic constitution" has been proposed by Ellis." While acute bronchiolitis may be associated with subsequent obstructive airways disease $\mathrm{e}^{2-4}$ no previous study has compared the atopic status in patients with acute bronchiolitis with that of a control group during an epidemic of respiratory syncytial virus. We report here the results of such a study.

\section{Patients and methods}

Study group-All children of less than 1 year and weighing $\geqslant 3 \mathrm{~kg}$ who were admitted to two general wards of the hospital over three months (December 1979 to February 1980) with a diagnosis of acute bronchiolitis were included in the study. Since previous authors have failed to agree on a precise definition of acute bronchiolitis, the diagnosis was based on the following clinical features: a history of preceding upper respiratory tract infection; acute onset of illness; dyspnoea and

Regional Blood Transfusion Service, Royal Infirmary, Edinburgh PENG LEE YAP, PHD, MRCPATH, senior registrar 
tachypnoea; hyperinflation of the chest (both clinical and radiological); and chest recession. Unproductive cough, mild fever, wheeze, rhonchi, and crepitations were variable features. At least two of us had to agree before the diagnosis was accepted.

Control group-This consisted of all acute admissions to these two wards during the same period. The infants were of similar age, and weight to the study group; the predominance of boys in the study group was not statistically significant (table I). The sole difference

TABLE I-Comparison of clinical data in infants with bronchiolitis (study group) and controls

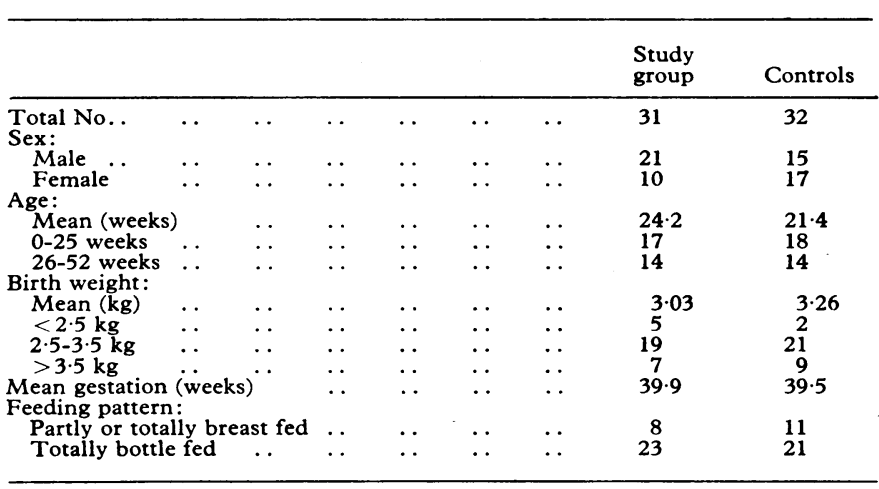

TABLE II-Clinical and laboratory results in 31 infants with bronchiolitis (study group) and 32 controls

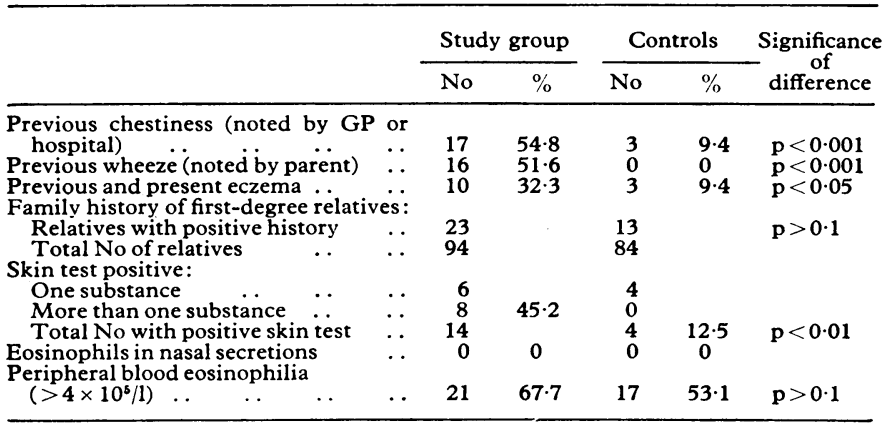

15 minutes. If the wheal was larger than $2 \mathrm{~mm}$ the reaction was judged to be positive. ${ }^{6}$ No child was taking antihistamines and no control solution produced a wheal larger than $1 \mathrm{~mm}$ in diameter. Absolute peripheral eosinophil count was made and serum immunoglobulin concentrations measured either by laser nephelometry, ${ }^{7}$ using monospecific antisera (Scottish Antibody Production Unit), or by radioimmunoassay (IgE only) (Pharmacia). Slides of nasal secretions ${ }^{8}$ were examined for eosinophils after Papanicolaou staining. All general practitioners of the 31 patients in the study group were asked about their referral policy in respiratory disease in infants.

Statistical analysis-Index patients and the control group were compared using either $2 \times 2$ contingency tables or Wilcoxon's rank sum test for unpaired measurements; immunoglobulin estimations were analysed according to age group. In comparing log means $\mathrm{p}$ values were obtained by Student's $t$ test.

\section{Results}

Of the 31 patients in whom acute bronchiolitis was diagnosed, 27 $(87.1 \%)$ had respiratory syncytial virus in upper respiratory tract secretions, as shown by the fluorescent antibody test. Ten of the controls had upper respiratory tract symptoms and, of these, five had positive results for respiratory syncytial virus.

The infants with acute bronchiolitis had a significantly higher incidence of previous respiratory illness requiring attendance by a general practitioner or admission to hospital (table II); significantly more also had a past history of atopic dermatitis. Although more of the study group had a family history of atopy and eczematous lesions the difference between the two groups was not statistically significant. Peripheral blood eosinophil counts were similar in both groups but nasal eosinophils were absent in both.

The difference between the results of the skin test in both groups was highly significant (table II). Furthermore, eight infants in the study group had positive reactions to two or more solutions whereas none of the 32 controls reacted to more than one solution.

Table III shows the results of serum immunoglobulin concentrations measured on 29 patients with bronchiolitis and 25 controls; the concentrations in infants with two bronchiolitis and six controls could not be accurately estimated for technical reasons. There were no significant differences between the two groups. Because of the alteration of serum immunoglobulin concentrations with age during the first year of life, ${ }^{910}$ the data were also analysed by subdividing both groups into the following age groups: 0-13 weeks, 14-26 weeks, 27-39 weeks, and 40-52 weeks. Again, no significant differences were found.

TABLE III-Immunoglobulin concentrations in 29 infants with bronchiolitis (study group) and in 25 controls

\begin{tabular}{|c|c|c|c|c|c|c|c|c|}
\hline \multirow[b]{2}{*}{ Immunoglobulins } & \multicolumn{3}{|c|}{ Study group } & \multicolumn{3}{|c|}{ Controls } & \multirow[b]{2}{*}{$\begin{array}{c}\text { Mean } \\
\text { difference }\end{array}$} & \multirow[b]{2}{*}{ Probability } \\
\hline & $\begin{array}{c}\text { Geometric } \\
\text { mean }\end{array}$ & $\underset{\text { mean }}{\log }$ & $\begin{array}{c}S D \text { of } \log \\
\text { from log mean }\end{array}$ & $\begin{array}{c}\text { Geometric } \\
\text { mean }\end{array}$ & $\underset{\text { mean }}{\log }$ & $\begin{array}{l}\mathrm{SD} \text { of } \log \\
\text { from log mean }\end{array}$ & & \\
\hline $\begin{array}{c}\operatorname{IgC}(\mathrm{g} / \mathrm{l}) \\
\operatorname{IgA}(\mathrm{g} / \mathrm{l}) \\
\operatorname{IgM}(\mathrm{g} / \mathbf{l}) \\
\operatorname{IgE}(\mathrm{IU} / \mathrm{ml})\end{array}$ & $\begin{array}{l}3 \cdot 284 \\
0 \cdot 347 \\
0 \cdot 747 \\
4 \cdot 279\end{array}$ & $\begin{array}{r}0.516 \\
-0.459 \\
-0.127 \\
0.631\end{array}$ & $\begin{array}{l}0 \cdot 187 \\
0 \cdot 313 \\
0 \cdot 234 \\
0 \cdot 602\end{array}$ & $\begin{array}{l}4 \cdot 210 \\
0 \cdot 328 \\
0 \cdot 722 \\
2 \cdot 902\end{array}$ & $\begin{array}{r}0.624 \\
-0.484 \\
-0.142 \\
0.463\end{array}$ & $\begin{array}{l}0.248 \\
0.406 \\
0.043 \\
0.846\end{array}$ & $\begin{array}{r}-0.108 \\
0.025 \\
0.015 \\
0.168\end{array}$ & $\begin{array}{l}>0.05 \\
>0.7 \\
>0.7 \\
>0.4\end{array}$ \\
\hline
\end{tabular}

was the lack of clinical evidence of lower respiratory tract infection in the controls. Since coincident atopy might have occurred in either group, a control who had a confirmed milk allergy was not excluded from the study.

Previous and family history-Details of previous wheeze, skin problems, or chest infections severe enough to require attendance by a general practitioner or admission to hospital, and a thorough family history of asthma, eczema, and hay fever or allergic rhinitis in parents or siblings or the patients were obtained from the parents of children in both groups. The total number of first-degree relatives was also recorded. The children were examined and any eczema noted and graded. ${ }^{5}$

Laboratory tests of atopy-With the verbal consent of the parents, the prick test using Bencard solutions was carried out on the backs of all infants during the early recovery phase when the child could tolerate the procedure without distress. House dust, Dermatophagoides pteronyssimus, milk, grasses, feathers, and a control solution were used: the mean diameters of both erythema and wheal were recorded after

\section{Discussion}

During an epidemic of respiratory syncytial virus in the Edinburgh area 31 children with acute bronchiolitis required hospital admission to two general paediatric wards. These infants probably represented the severe end of the spectrum. This impression was supported by discussion with all the general practitioners concerned with the referrals. Since respiratory syncytial virus infection was identified in some controls immediately after admission many other children in the general population were probably also infected even though they did not develop lower respiratory problems. Because infants with acute bronchiolitis had a significantly increased incidence of some atopic features compared with the controls, an allergic diathesis may predispose to bronchiolitis in response to a viral infection. Previous infection with respiratory syncytial virus may sensitise the infant ${ }^{11}$ which may then produce an allergic reaction on sub- 
sequent exposure to the virus. Furthermore, more severe reactions to infection with the virus have occurred after inoculation with respiratory syncytial virus vaccine. ${ }^{12}$

Although a recent retrospective study ${ }^{13}$ on 8 -year old children showed no difference in the prevalence of atopy between 26 patients who had had acute bronchiolitis in infancy and paired controls, its findings do not compare directly with those of the present study.

In studies of the connection between acute bronchiolitis and subsequent asthma Zweiman et $a l^{14}$ found retrospectively that $40-50 \%$ of children admitted to hospital because of acute bronchiolitis had recurrent wheeze subsequently and that the risk of this was higher when there was a family history of atopy or the patient showed other allergic manifestations. Bronchiolitis due to respiratory syncytial virus associated with subsequent wheezing was also found in a retrospective study by Rooney and Williams, ${ }^{2}$ in which $72 \%$ of those with recurrent wheeze had a family history of atopy. Hyde and Saed ${ }^{3}$ found that $39 \%$ of infants less than 1 year old who presented with bronchiolitis subsequently had a recurrent wheeze and that $78 \%$ of those had a family history of atopy or allergic manifestations. Given that childhood asthma is partly an allergic condition, the fact that a high proportion of those with acute bronchiolitis (particularly those with atopic features) have subsequent episodes of wheeze supports the view that acute bronchiolitis may occur more frequently in an atopic population.

We thank Dr W M McCrae and Dr W S Uttley for allowing us to include their patients in the study. We are also very grateful to Mrs D Tervit and Miss D McKay for their meticulous secretarial help in preparation of this paper.

Correspondence should be addressed to Dr Ian Laing, Royal Hospital for Sick Children, Sciennes Road, Edinburgh EH9 1LF.

\section{References}

${ }^{1}$ Ellis EF. Relationship between the allergic state and susceptibility to infectious airway disease. Pediatr Res 1977;11:227-9.

${ }^{2}$ Rooney JC, Williams HE. The relationship between proved viral bronchiolitis and subsequent wheezing. I Pediatr 1971;79:744-7.

${ }^{3}$ Hyde JS, Saed AM. Acute bronchiolitis and the asthmatic child. $\mathcal{F}$ Asthme Res 1966;4:137-54.

${ }^{4}$ Eisen AH, Bacal HL. Relationship of acute bronchiolitis to bronchial asthma. Pediatrics $1963 ; 31: 859-61$.

${ }^{5}$ Matthew DJ, Norman AP, Taylor B, Turner MW, Soothill JF. Prevention of eczema. Lancet $1977 ; \mathrm{i}: 321-4$.

${ }^{6}$ Foucard T. A follow-up study of children with asthmatoid bronchitis. Acta Paediatr Scand 1973;62:633-44.

7 Whicher JT, Perry DE, Hobbs JR. An evaluation of the Hyland laser nephelometer PDQ system. Ann Clin Biochem 1978;15:77-85.

${ }^{8}$ Murray AB, Anderson DO. The epidemiologic relationship of clinical nasal allergy to eosinophils and to goblet cells in the nasal smear. fournal of Allergy $1969 ; 43: 1-8$.

${ }^{9}$ Berg T. The immunoglobulin development during the first year of life. Acta Paediatr Scand 1969;58:229-36.

${ }^{10}$ Berg T, Johansson SGO. Immunoglobulin levels during childhood with special regard to IgE. Acta Paediatr Scand 1969;58:513-24.

11 McIntosh K, Ellis EF, Hoffmann LS, Tillingast GL, Eller JJ, Fulginiti VA. The association of viral and bacterial respiratory infections with exacerbations of wheezing in young asthmatic children. $\mathcal{f}$ Paediatr 1973;82:578.

12 Kapikian AZ, Mitchell RH, Chanock RM, Shvedoff RA, Stewart CE. An epidemiological study of altered clinical reactivity to RSV infection in children previously vaccinated with an inactivated RS virus vaccine. Am $\mathcal{F}$ Epidemiol 1969;89:405.

${ }^{13}$ Sims DG, Gardner PS, Weightman D, Turner MW, Soothill JF. Atopy does not predispose to RSV bronchiolitis or post-bronchiolitic wheezing. Br Med $\mathcal{f} 1981 ; 282: 2086-8$.

14 Zweiman B, Schoenwetter WF, Pappano JE Jr, et al. Patterns of allergic respiratory disease in children with a past history of bronchiolitis. f Allergy Clin Immunol 1971;48:283-9.

(Accepted 27 fanuary 1982)

\title{
Nuclear magnetic resonance studies of forearm muscle in Duchenne dystrophy
}

\author{
RAYMOND J NEWMAN，PETER J BORE，LAWRENCE CHAN， DAVID G GADIAN, \\ PETER STYLES, DORIS TAYLOR, GEORGE K RADDA
}

\begin{abstract}
The forearms of six patients with Duchenne dystrophy were examined by the painless and non-invasive technique of high-resolution nuclear magnetic resonance spectroscopy. The phosphorus spectrum was abnormal in that the ratios of phosphocreatine to adenosine triphosphate
\end{abstract}

\footnotetext{
Nuffield Department of Orthopaedic Surgery, Nuffield Orthopaedic Centre, Oxford OX3 7LD

RAYMOND J NEWMAN, BSC, FRCS, research fellow and honorary senior registrar

Department of Biochemistry, University of Oxford, Oxford OX1 3QU

PETER J BORE, BSC, FRCS, research fellow

DAVID G GADIAN, MA, DPHIL, research fellow

PETER STYLES, BSC, research assistant

DORIS TAYLOR, DPHIL, research assistan

GEORGE K RADDA, DPHIL, FRS, lecturer
}

Nuffield Department of Medicine, University of Oxford, John Radcliffe Hospital, Oxford OX3 9DU

LAWRENCE CHAN, MB, MRCP, clinical lecturer and to inorganic phosphate were reduced. Absolute quantification under the conditions of this experiment was not possible but it was probable that in dystrophy the concentration of phosphocreatine in muscle was appreciably reduced. A signal in the phosphodiester region of the spectrum was recorded consistently in patients with dystrophy but not in controls. The intracellular pH of the muscle in the dystrophic patients was abnormally alkaline.

The clinical application of nuclear magnetic resonance spectroscopy remains to be proved, but it appears to be a promising non-invasive technique for investigating biochemical abnormalities of muscle disease.

\section{Introduction}

The muscular dystrophies are characterised by progressive degeneration of muscle but not affecting the nervous system. The commonest form is Duchenne dystrophy, which is transmitted by an X-linked recessive gene. Signs of the disease usually appear within the first three years of life and are most noticeable in the legs. An initial enlargement of the muscles gives way to profound weakness and wasting, and death from inanition or 